\title{
A Novel Amperometric Biosensor Based on Poly(allylamine hydrochloride) for Determination of Ethanol in Beverages
}

\author{
Oana Maria Istrate ${ }^{1,+}$, Lucian Rotariu ${ }^{1,2,+}$ and Camelia Bala ${ }^{1,2, *(D)}$ \\ 1 LaborQ, University of Bucharest, 030018 Bucharest, Romania; oana-maria.dumitrascu@cdi.unibuc.ro (O.M.I.); \\ lucian.rotariu@g.unibuc.ro (L.R.) \\ 2 Department of Analytical Chemistry, University of Bucharest, 030018 Bucharest, Romania \\ * Correspondence: camelia.bala@chimie.unibuc.ro; Tel.: +40-214104888 \\ + These authors contributed equally to this work.
}

Citation: Istrate, O.M.; Rotariu, L.; Bala, C. A Novel Amperometric

Biosensor Based on Poly(allylamine hydrochloride) for Determination of Ethanol in Beverages. Sensors 2021,

21, 6510. https://doi.org/

$10.3390 / \mathrm{s} 21196510$

Academic Editor: José

Manuel Díaz-Cruz

Received: 27 August 2021

Accepted: 26 September 2021

Published: 29 September 2021

Publisher's Note: MDPI stays neutral with regard to jurisdictional claims in published maps and institutional affiliations.

Copyright: (C) 2021 by the authors. Licensee MDPI, Basel, Switzerland. This article is an open access article distributed under the terms and conditions of the Creative Commons Attribution (CC BY) license (https:/ / creativecommons.org/licenses/by/ $4.0 /)$.

\begin{abstract}
Herein, we report on a new type of ethanol biosensor based on a screen-printed electrode modified with poly(allylamine hydrochloride). The alcohol dehydrogenase was immobilized on the surface of the sensor using the sol-gel matrix. Working parameters such as applied potential, $\mathrm{pH}, \mathrm{NAD}^{+}$concentration, storage conditions were optimized. A response range between 0.05 and $2 \mathrm{mM}$ was found with a sensitivity of $13.45 \pm 0.67 \mu \mathrm{A} / \mathrm{mM} \cdot \mathrm{cm}^{2}$ and a detection limit of $20 \mu \mathrm{M}$. The developed biosensor was used to detect ethanol in commercial beverages with good accuracy.
\end{abstract}

Keywords: alcohol dehydrogenase; biosensor; screen-printed electrode; ethanol

\section{Introduction}

Ethanol is one of the most important organic chemicals in human activities with a variety of uses in food industry, chemical synthesis, medicine and biotechnology. Ethanol can appear as a bi-product in various processes in the food industry and can reach harmful levels due to fermentation and distillation. It also causes alcohol poisoning in direct consumption by humans. For these reasons, ethanol detection is of great importance for clinical and industrial applications. Some of the most common detection methods for ethanol include high performance liquid chromatography [1], gas chromatography [2], capillary electrophoresis [3], colorimetry [4], Raman spectrometry [5], or tandem techniques [6,7]. Although some of the above methods are complex and reliable, they can have disadvantages such as the need to use previous processes of sample separation (distillation, pervaporation), can be time consuming, and instruments can be expensive and need trained operators.

The enzyme-based biosensors represent an attractive solution to overcome all these disadvantages. The use of biosensors for the quantitative analysis of ethanol offers several advantages, such as sensitivity, versatility, low cost and the possibility of miniaturization and integration into portable systems. Other advantages make reference to the fact that the biosensors do not require qualified personnel and laborious sample treatments. Enzymatic biosensors have evolved rapidly and are used successfully in clinical analysis [8], in the analysis of food [9] and alcoholic beverages [10]. The enzymes involved in the development of biosensors for ethanol detection are alcohol dehydrogenase (ADH) [11] and alcohol oxidase [12]. ADH is the most used in the development of enzymatic biosensors for ethanol detection, where the substrate detection is performed by measuring the amount of NADH formed in the enzymatic reaction.

One of the most important steps in the development of an electrochemical biosensor is the immobilization of the enzyme on the electrode surface. Literature reports different materials used for the immobilization of $\mathrm{ADH}$, including cationic polymers [13], nanobiocomposites based on polyelectrolytes and carbon materials [14], graphene-Au nanorods hybrid nanosheets [15]. The use of these composite materials leads also to an enhancement 
of the electrochemical detection of NADH that finally improve the performances of the ethanol biosensors.

Polyelectrolytes are a wide class of compounds used as coating materials as well as immobilization matrices for some biomolecules in the development of biosensors [16,17]. The deposition of the polyelectrolyte layer on the electrode surface increases the active area of the electrode, and due to the electrostatic interaction between the analyte and the polyelectrolyte, leads to its accumulation on the electrode surface that can enhance the electrochemical detection of the analyte.

Herein, we report a new amperometric biosensor with immobilized alcohol dehydrogenase for the detection of ethanol in commercial beverages. Alcohol dehydrogenase was entrapped into a sol-gel matrix that was immobilized on the surface of screen-printed electrode (SPE) modified with poly(allylamine hydrochloride). The PAH/SPE enhances the accumulation of the NADH at the surface of the electrode and leads to an increase of the oxidation current, as was previously reported [18]. A schematic representation of the biosensor is shown in Scheme 1. The optimization of the working parameters and the characterization of the biosensor was performed by using amperometry.

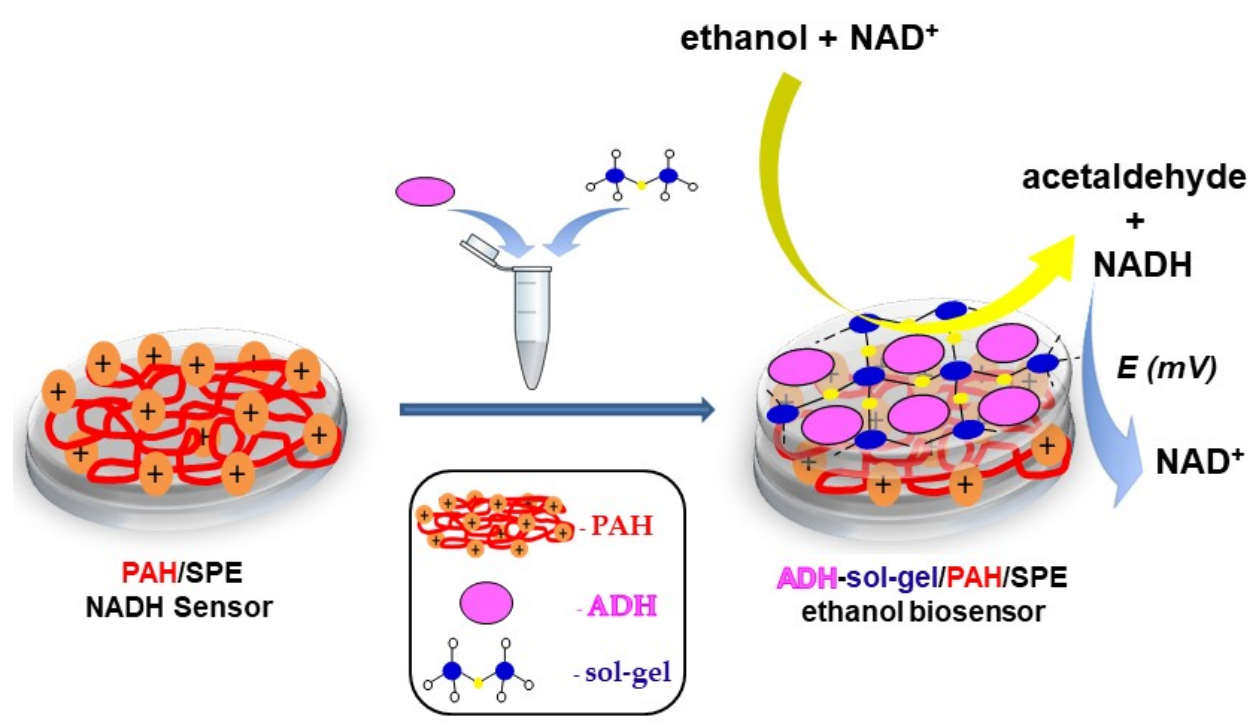

Scheme 1. Schematic representation of the ethanol biosensor.

\section{Materials and Methods}

\subsection{Reagents}

Alcohol dehydrogenase from braker's yeast (ADH, 75,000 IU/g solid), nicotinamide adenine dinucleotide hydrate $\left(\mathrm{NAD}^{+}\right)$, nicotinamide adenine dinucleotide reduced disodium salt (NADH), poly(allylamine hydrochloride) (PAH, MW $15 \mathrm{kDa}$ ), ethanol, ascorbic acid (AA), uric acid (UA), dopamine (DA), glucose (Glu) and acetaminophen (APAP), hydrochloric acid $(\mathrm{HCl})$ were purchased from Sigma Aldrich and were used as received without further purification. Tetramethoxysilane (TMOS), methyltrimethoxysilane (MTMOS) and polyethylene glycol (PEG 600) were purchased from Fluka (Fluka Chemie $\mathrm{GmbH}$, Buchs, Switzerland). All other chemicals were of analytical grade. Phosphate buffer (PBS) $0.1 \mathrm{M}, \mathrm{pH}=8.8$ was prepared from $\mathrm{Na}_{2} \mathrm{HPO}_{4}$ and $\mathrm{NaH}_{2} \mathrm{PO}_{4}$ and contains $0.1 \mathrm{M} \mathrm{KCl}$. All solutions were prepared in ultrapure water (Millipore $18 \mathrm{M} \Omega \cdot \mathrm{cm}$ ).

\subsection{Equipment and Materials}

The Autolab PGSTAT 101 (Metrohm-Autolab B.V., Utrecht, The Netherlands) electrochemical workstation was used for cyclic voltammetry and amperometric measurements. Screen-printed electrodes (SPE) from Dropsens (Metrohm Dropsens, Oviedo, Spain) based on carbon working electrode; silver pseudo-reference electrode and carbon counter electrode (DRP-C110) were used for the preparation of the ADH biosensor. All potentials 
are reported vs. silver pseudo-reference electrode. All measurements were performed at room temperature. A magnetic stirrer was used to provide a constant convective transport during the amperometric measurements. The enzyme activity was determined spectrometrically using a Shimadzu UV-1650PC UV-VIS spectrophotometer (Shimadzu, Kyoto, Japan) by monitoring the NADH at $340 \mathrm{~nm}$. Scanning electron microscopy (SEM) images were recorded with a Carl Zeiss AURIGA CrossBeam Workstation at an accelerating voltage of $2 \mathrm{kV}$. pH measurements were performed with an InoLab WTW pH $730 \mathrm{pH}-$ meter (Inolab WTW, Weilheim, Germany).

\subsection{Preparation of PAH Modified Screen Printed Electrodes}

Prior their modification, the screen-printed electrodes were pretreated using cyclic voltammetry by scanning the potential on the range -500 and $+500 \mathrm{mV}$ in PBS $(0.1$ $\mathrm{M}, \mathrm{pH}=6$ ) until reproducible voltammograms were obtained. This pretreatment, which leads to a negatively charged electrode surface, favors the formation and stabilization of the cationic polyelectrolyte film (PAH). The procedure has been previously published elsewhere [18]. After pretreatment, $5 \mu \mathrm{L}$ aqueous PAH solution $(0.5 \mathrm{mg} / \mathrm{mL})$ was deposited on the surface of the working electrode and then the electrode was left to dry at room temperature for $24 \mathrm{~h}$.

PAH modified SPE sensor was previously optimized and the reported results shown an enhanced electrochemical detection of NADH [18]. This sensor was used as NADH transducer for preparation of an ethanol biosensor based on immobilized ADH.

\subsection{Preparation of ADH-Sol-Gel/PAH/SPE Biosensor}

Alcohol dehydrogenase (ADH) was immobilized in a sol-gel matrix taking into account the simplicity and efficiency of the procedure that preserve the enzyme activity for a long period [19]. The enzyme activity of ADH was determined prior the immobilization. $\mathrm{NADH}$ produced in the enzyme reaction was detected by spectrometry at $340 \mathrm{~nm}$ [20]. The kinetic measurements allowed us to determine the enzyme reaction rate and express the real enzyme activity.

The immobilization matrix was prepared by mixing $5 \mu \mathrm{L}$ of TMOS with $15 \mu \mathrm{L}$ MTMOS, $40 \mu \mathrm{L} \mathrm{HCl}(20 \mathrm{mM}), 44 \mu \mathrm{L}$ ultrapure water and $4 \mu \mathrm{L}$ PEG 600 [21]. The mixture was sonicated for about $15 \mathrm{~min}$ and then kept at $4{ }^{\circ} \mathrm{C}$ for about $6 \mathrm{~h}$. After hydrolysis of the precursors and formation of the so-called "sol", $10 \mu \mathrm{L}$ of sol was mixed with $10 \mu \mathrm{L}$ ADH (20 IU) and finally, $5 \mu \mathrm{L}$ was dropped on the surface of working electrode modified with PAH film. Subsequently, the biosensor was left to dry for $24 \mathrm{~h}$ in desiccator at $4{ }^{\circ} \mathrm{C}$ in order to favor the condensation reaction and entrapment of the enzyme in polymer network of the sol-gel. The procedure was optimized in order to immobilize $5 \mathrm{IU}$ of ADH on each $\mathrm{PAH} / \mathrm{SPE}$ sensor.

\section{Results}

\subsection{Morphological Characterization of the Electrodes}

The surface morphology of SPE, PAH/SPE and ADH-sol-gel/PAH/SPE electrodes was studied by scanning electron microscopy (SEM). As one can see in the Figure 1A, the image of bare SPE electrode shows irregular flakes of graphite, which are randomly oriented. The SEM micrograph of the PAH film deposited onto the SPE electrode (Figure 1B) evidenced an ordered hemispherical morphology that provides a high active surface of the modified electrode. A smoother surface was observed after immobilization of the enzyme using sol-gel with small particles ascribed to the condensation process of "sol" in the presence of ADH (Figure 1C). 

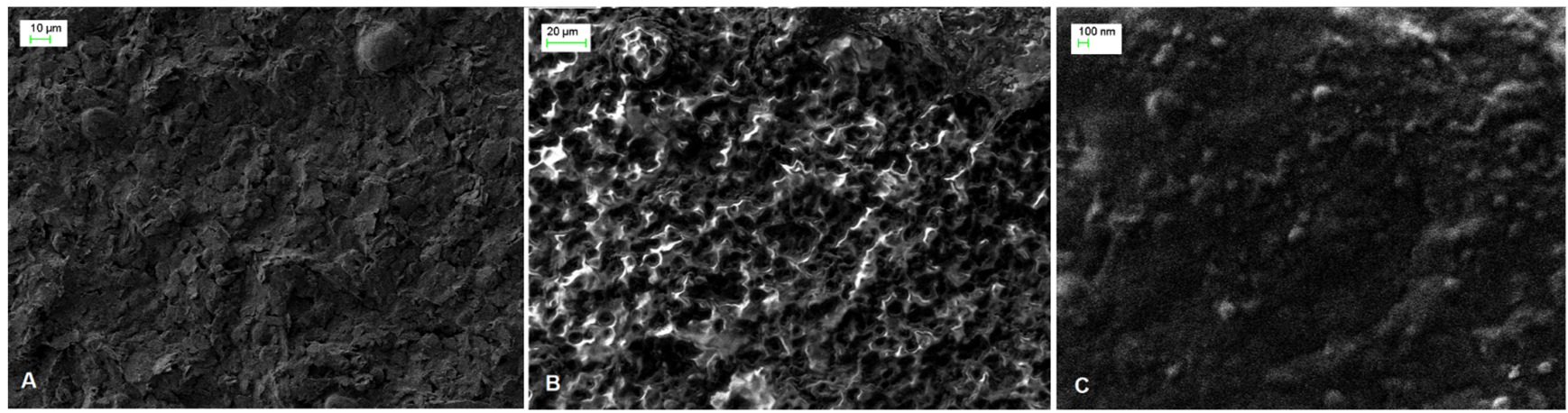

Figure 1. SEM images of (A) SPE, (B) PAH/SPE and (C) ADH-sol-gel/PAH/SPE sensors.

\subsection{Optimization of Working Potential}

The working potential influences the sensitivity of an amperometric biosensor and optimization of the applied potential leads to a significant improvement of the performances of the biosensor. The optimization of the working potential of ADH-sol-gel/PAH/SPE biosensor was achieved by chronoamperometric measurements in the presence of $4 \mathrm{mM}$ ethanol and $10 \mathrm{mM} \mathrm{NAD}^{+}$at applied potentials between $+400 \mathrm{mV}$ and $+800 \mathrm{mV}$. The steady state currents before and after addition of ethanol were recorded. The variation of the current after addition of ethanol was graphically represented upon the applied potential as it can be seen in the Figure 2. A significant increase of the analytical signal can be observed from $+400 \mathrm{mV}$ to $+500 \mathrm{mV}$, where it reaches a maximum value of $2.1 \mu \mathrm{A}$. At higher potentials, the current decreases and reaches approximately $1.2 \mu \mathrm{A}$ at $+800 \mathrm{mV}$. The potential of $+500 \mathrm{mV}$ was considered the optimal working potential and it was used further for all successive measurements.

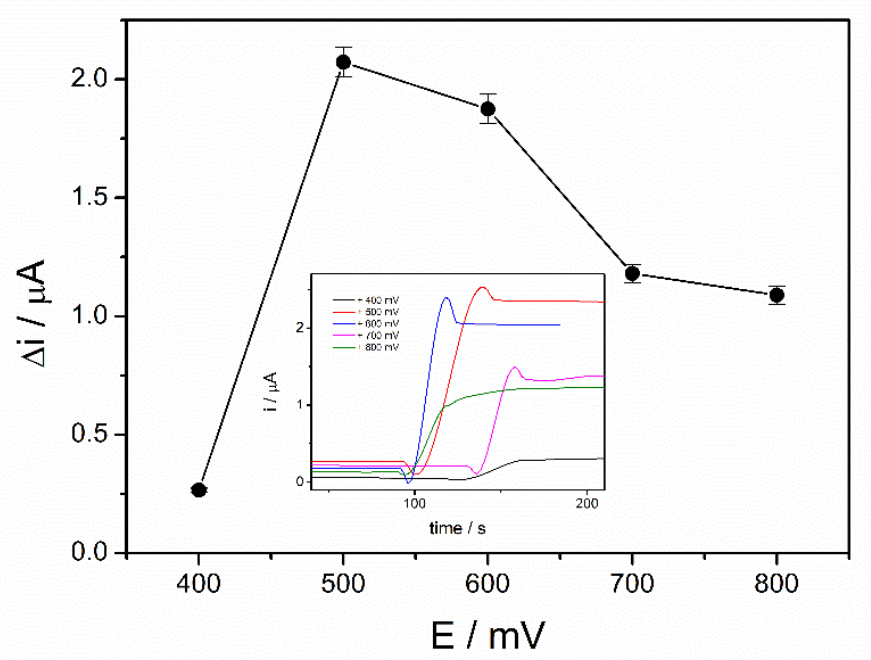

Figure 2. Influence of working potential on the biosensor response (PBS $0.1 \mathrm{M} \mathrm{pH}=8.8,10 \mathrm{mM}$ $\mathrm{NAD}^{+}, 4 \mathrm{mM}$ ethanol, $\mathrm{n}=3$ ) (inset: chronoamperometric response curves at an applied potential between +400 and $+800 \mathrm{mV})$.

\subsection{Optimization of the Working $\mathrm{pH}$}

Enzymatic oxidation of ethanol in the presence of $\mathrm{ADH}$ is dependent on the $\mathrm{pH}$. Moreover, the enzyme immobilization method can affect the working $\mathrm{pH}$ of the ethanol biosensor. Therefore, in order to find the optimal working $\mathrm{pH}$, the chronoamperograms were recorded in the presence of $4 \mathrm{mM}$ ethanol and $10 \mathrm{mM} \mathrm{NAD}^{+}$and the $\mathrm{pH}$ of PBS buffer $0.1 \mathrm{M}$ was varied in the range from 6 to 10 . A significant increase of the analytical signal was observed over the $\mathrm{pH}$ range of 6-8 with a maximum reached between 8 and 9 , as can be seen in Figure 3. The NADH oxidation current decreases at higher $\mathrm{pH}$, corresponding to 
a lower reaction rate. The optimal $\mathrm{pH}$ of alcohol dehydrogenase reported in the literature ranges between 8 and 9 [22]. An optimal $\mathrm{pH}$ of 8.8 for the immobilized $\mathrm{ADH}$ is in the above-mentioned range, which proves that the sol-gel matrix does not modify the enzyme properties. The immobilized enzyme seems to act similar to the native enzyme. As a hydrophilic matrix, the sol-gel preserves the enzyme activity and does not hinder the interaction with the substrate [19]. All subsequent studies were performed at $\mathrm{pH}$ of 8.8.

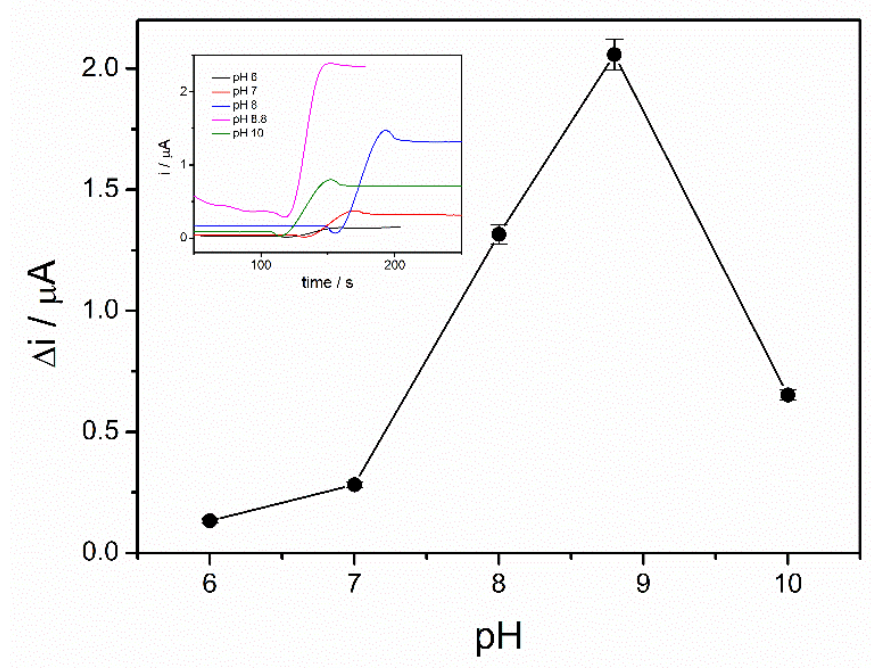

Figure 3. Influence of $\mathrm{pH}$ on the biosensor response (PBS $0.1 \mathrm{M}, 10 \mathrm{mM} \mathrm{NAD}{ }^{+}, 4 \mathrm{mM}$ ethanol, $\mathrm{n}=3$ ) (inset: chronoamperometric response curves at $\mathrm{pH}$ between 6 and 10).

\subsection{Optimization of the Coenzyme Concentration}

The coenzyme $\left(\mathrm{NAD}^{+}\right)$plays an important role in the oxidation of the ethanol in the presence of $\mathrm{ADH}$. The highest reaction rate and, consequently, the highest biosensor response can be achieved if an excess of $\mathrm{NAD}^{+}$is provided. In order to study the influence of $\mathrm{NAD}^{+}$concentration on the response of the $\mathrm{ADH}$-sol-gel/PAH/SPE biosensor, chronoamperometric measurements were performed at an applied potential of $+500 \mathrm{mV}$ in $0.1 \mathrm{M}$ PBS buffer, $\mathrm{pH}=8.8$, and an ethanol concentration of $4 \mathrm{mM}$. The concentration of $\mathrm{NAD}^{+}$was varied between 0.5 and $18 \mathrm{mM}$. Figure 4 , which exhibits the response of the ethanol biosensor in the presence of different concentration of $\mathrm{NAD}^{+}$, shows an increase of the oxidation current on the range $0.5-10 \mathrm{mM} \mathrm{NAD}^{+}$. The decrease of the signal at concentrations higher than $10 \mathrm{mM}$ can be attributed to an electrode surface blocking effect. The diffusion issues inside the sol-gel matrix and the accumulation of the $\mathrm{NAD}^{+}$at the surface of the electrode can explain this behavior.

Consequently, a concentration of $10 \mathrm{mM} \mathrm{NAD}^{+}$was considered optimal and it was used for biosensor calibration and detection of ethanol in real samples. 


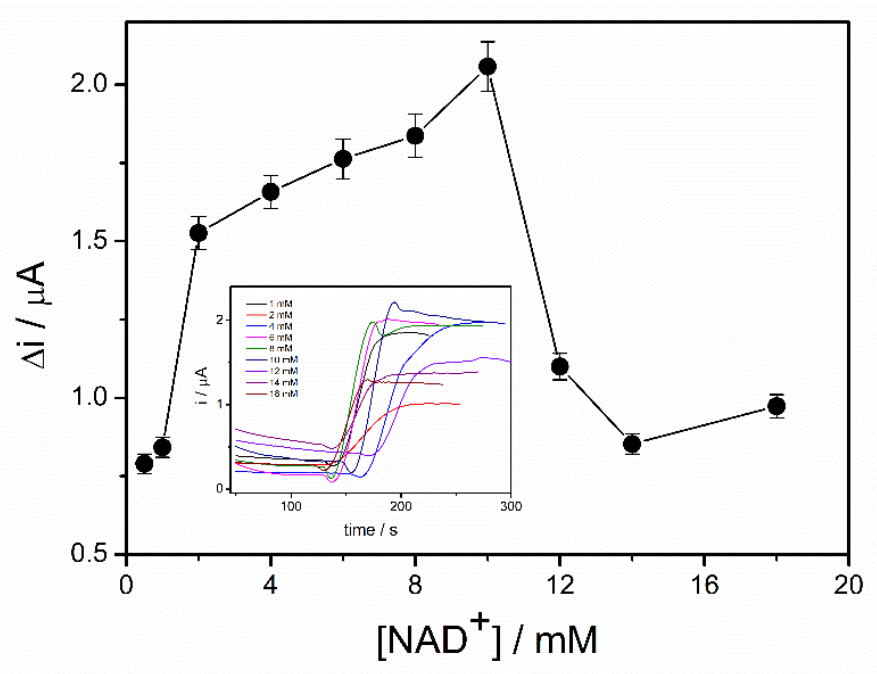

Figure 4. Influence of $\mathrm{NAD}^{+}$concentration on the biosensor response $(\mathrm{E}=+500 \mathrm{mV}, \mathrm{PBS} 0.1 \mathrm{M}$ $\mathrm{pH}=8.8,4 \mathrm{mM}$ ethanol, $\mathrm{n}=3$ ) (inset: chronoamperometric response curves recorded for $\mathrm{NAD}^{+}$ concentrations range $0.5-18 \mathrm{mM})$.

\subsection{Effect of the Rehydration on the Biosensor Response}

The preparation of the biosensors implies the immobilization of ADH in the sol-gel matrix. During the formation of the gel matrix, the biosensors were kept in a desiccator, which leads to its partial drying. Before using the ethanol biosensor, it is recommended to perform a rehydration of the biosensor in order to enhance the permeability of sol-gel and increase of the diffusion rate of the compounds involved in the enzyme reaction at the level of the electrode surface [23].

To rehydrate the sol-gel matrix, three biosensors, prepared in the same conditions, were kept in PBS buffer for different time ranging from 5 to $25 \mathrm{~min}$. Then, a calibration of each biosensor was performed in $0.1 \mathrm{M}$ PBS $(\mathrm{pH}=8.8)$, containing $10 \mathrm{mM} \mathrm{NAD}^{+}$. A difference of potential between working electrode and pseudo-reference electrode of $+500 \mathrm{mV}$ was applied and response of the biosensors were recorded to successive additions of ethanol. The Figure 5 shows the calibration curves of the three biosensors. For the whole range of ethanol concentrations, the highest signal was recorded after a hydration time of $15 \mathrm{~min}$., this being considered the optimal hydration time used for all subsequent measurements.

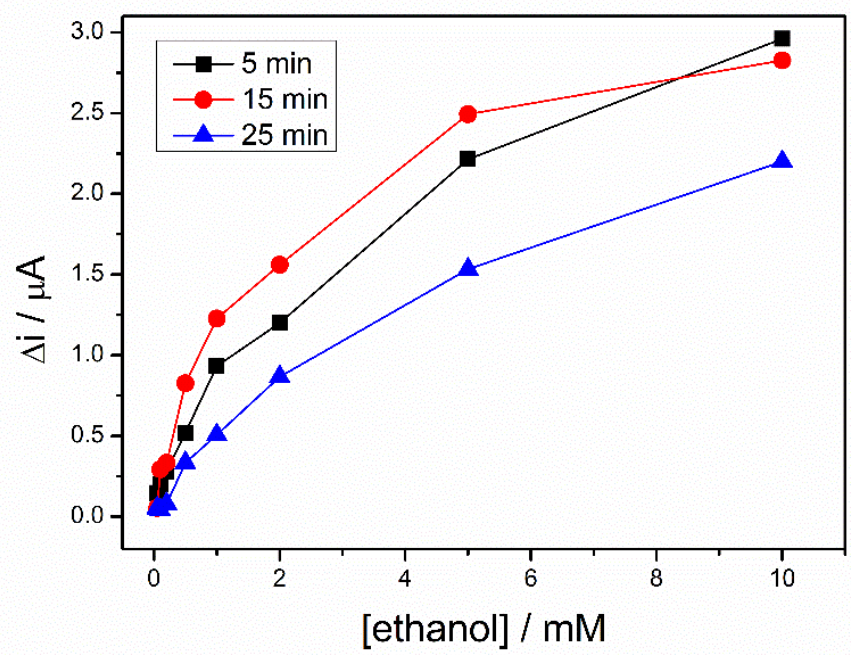

Figure 5. Calibration graph of ADH-sol-gel/PAH/SPE biosensors at different storage time in buffer solution, $5 \mathrm{~min}$ (black line), $15 \mathrm{~min}$ (red line), $25 \mathrm{~min}$ (blue line), $\left(\mathrm{E}=+500 \mathrm{mV}\right.$, [NAD ${ }^{+}$] $=10 \mathrm{mM}, \mathrm{PBS}$ $0.1 \mathrm{M} \mathrm{pH}=8.8)$. 


\subsection{Ethanol Biosensor Calibration}

Calibration of the ethanol biosensors was realized in a $5 \mathrm{~mL}$ electrochemical cell under continuous stirring in the optimized condition. A potential of $+500 \mathrm{mV}$ was applied after immersion of the biosensor in $5 \mathrm{~mL}$ of PBS buffer. After reaching the steady state signal, successive volumes of ethanol were added. A rapid stabilization of the analytical signal was observed after each addition, with a response time of $19 \mathrm{~s}$ for the entire range of concentrations tested, calculated to reach $90 \%$ of the steady state current value. The calibration curve of the biosensor corresponding to the range of ethanol concentrations between $0.05-10 \mathrm{mM}$ is shown in Figure 6, where each point represents the mean value for three measurements. For each ethanol concentration, the variation of the current was determined as the difference between the steady state current after the addition of ethanol and the steady state current for the buffer solution. Two linear domains were highlighted from the dynamic response range presented in the Figure 6. The first linear range corresponds to the domain between 50 and $200 \mu \mathrm{M}(\mathrm{i}(\mu \mathrm{A})=0.052+1.692 \cdot$ [ethanol] $(\mathrm{mM}))$, where a specific sensitivity of $13.45 \pm 0.67 \mu \mathrm{A} / \mathrm{mM} \cdot \mathrm{cm}^{2}$ was determined and a detection limit of $20 \mu \mathrm{M}$ was calculated for a signal-to-noise ratio of 3 . A specific sensitivity of $5.74 \pm 0.35 \mu \mathrm{A} / \mathrm{mM} \cdot \mathrm{cm}^{2}$ was calculated for the second linear range selected in the domain $0.2-2 \mathrm{mM}(\mathrm{i}(\mu \mathrm{A})=0.313$ $+0.721 \cdot[$ ethanol $](\mathrm{mM}))$. The calibration graph shows a saturation trend of the biosensor response at concentrations higher than $2 \mathrm{mM}$. Consequently, due to the low sensitivity of the biosensor in this range, the relevant response of the biosensor was limited to the range $50-2000 \mu \mathrm{M}$.

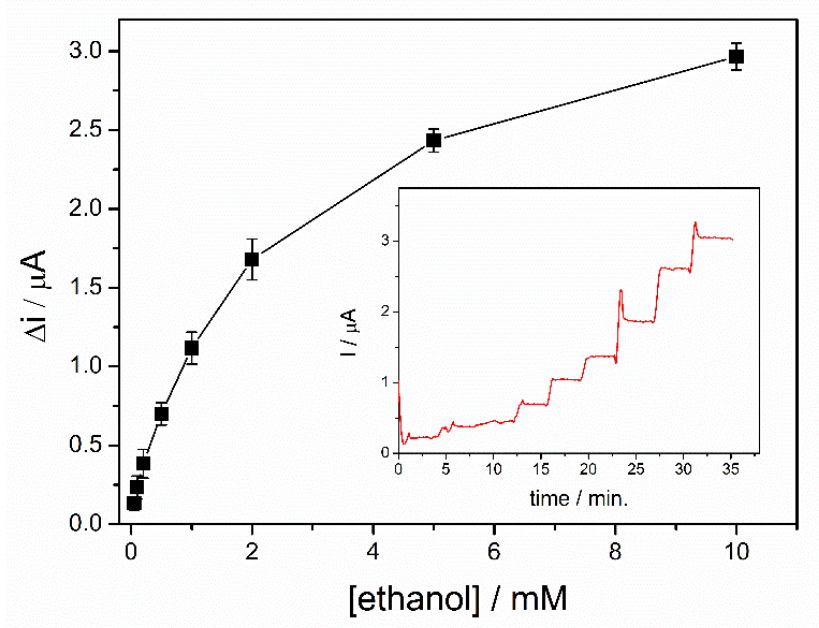

Figure 6. Dynamic response range of $\mathrm{ADH}$-sol-gel/PAH/SPE biosensor $(\mathrm{E}=+500 \mathrm{mV}$, $\left[\mathrm{NAD}^{+}\right]=10 \mathrm{mM}$, PBS $0.1 \mathrm{M} \mathrm{pH}=8.8, \mathrm{n}=3$ ) (inset: typical biosensor response curve).

Table 1 presents the performances of ethanol biosensors based on polymer modified electrodes reported in the literature. Compared to other enzyme biosensors for ethanol, the ADH-sol-gel/PAH/SPE biosensor exhibits high sensitivity, low detection limit for a response range of approximately two decades. 
Table 1. Comparison of the performances of some ethanol biosensors based on polymer modified electrodes.

\begin{tabular}{|c|c|c|c|c|c|c|}
\hline Electrode Material & $\mathrm{pH}$ & $\begin{array}{l}\text { Linear Range } \\
(\mu \mathrm{M})\end{array}$ & $\operatorname{LOD}(\mu \mathrm{M})$ & $\begin{array}{c}\text { Sensitivity } \\
\left(\mu \mathrm{A} / \mathrm{mM} \cdot \mathrm{cm}^{2}\right)\end{array}$ & RSD (\%) & Ref. \\
\hline MWCNTs-AuNPs-PNR & 7.75 & $320.2-1000$ & 96.1 & 3.9 & 1.57 & [11] \\
\hline RA & 7.75 & $23.71-1000$ & 7.1 & 10.83 & 1.65 & [24] \\
\hline MWCNTs-Polyarg & 7.4 & $5-1000$ & 0.65 & 21.04 & 5.5 & [25] \\
\hline PANI-PAAMPSA & 8.5 & $5-2000$ & N.R. & 5.19 & N.R. & [26] \\
\hline CNCs & 7 & $\sim 5000$ & 300 & 0.15 & 7.8 & {$[27]$} \\
\hline $\mathrm{TiO}_{2} / \mathrm{MWCNTs} /$ Nafion/MB & 7 & $50-1100$ & 25 & 7.93 & 7.3 & [28] \\
\hline $\mathrm{Fe}_{3} \mathrm{O}_{4} \mathrm{Au} / \mathrm{MnO}_{2}$ & 6.8 & $0.1-1 \mathrm{M}$ & 70 & 0.02 & 4.0 & [29] \\
\hline $\mathrm{MB}$ & 8 & $50-15,000$ & 80 & 0.94 & 3.8 & [30] \\
\hline $\mathrm{PVI}_{13}$ dmeOs-PEGDGE & 6 & $1-250$ & 1 & 3.36 & N.R. & {$[31]$} \\
\hline PAH & 8.8 & $\begin{array}{c}50-200 \\
200-2000\end{array}$ & 20 & $\begin{array}{c}13.45 \\
5.74\end{array}$ & 4.36 & This work \\
\hline
\end{tabular}

MWCNTs: multiwall carbon nanotube, AuNPs: gold nanoparticles, PNR: poly neutral red, RA: rosmarinic acid, Polyarg: polyarginine, PANI: polyaniline, PAAMPSA: poly(2acrylamido-2-methyl-1-propane, $\mathrm{CNCs}$ : carbon nanocages, $\mathrm{TiO}_{2}$ : titania sol gel, MB: Meldola's Blue, $\mathrm{Fe}_{3} \mathrm{O}_{4} \mathrm{Au}$ : gols magnetic nanoparticles, $\mathrm{MnO}_{2}$ : manganese dioxide, $\mathrm{PVI}_{13}$ dmeOs: $\left[\mathrm{Os}(4,4\right.$-dimethylbipyridine $\left.) 2 \mathrm{Cl}_{2}\right]+/ 2+$ and poly(1-vinylimidazole), PEGDGE: poly ethylene glycol diglycidyl ether, N.R.: not reported.

\subsection{Stability of the ADH-Sol-Gel/PAH/SPE Biosensor}

The operational stability of the ADH-sol-gel/PAH/SPE biosensor was studied by performing successive measurements of the same concentration of ethanol during the same day. These measurements were performed in $0.1 \mathrm{M}$ PBS buffer, $\mathrm{pH}=8.8$ in the presence of $10 \mathrm{mM} \mathrm{NAD}{ }^{+}$and $4 \mathrm{mM}$ ethanol every $2 \mathrm{~min}$. Between measurements, the biosensor was stored in phosphate buffer solution. The biosensors response for 10 successive measurements is presented in Figure 7A. The relative standard deviation (RSD) was 4.4\% for 10 measurements, which illustrates a very good operational stability of the ethanol biosensor.
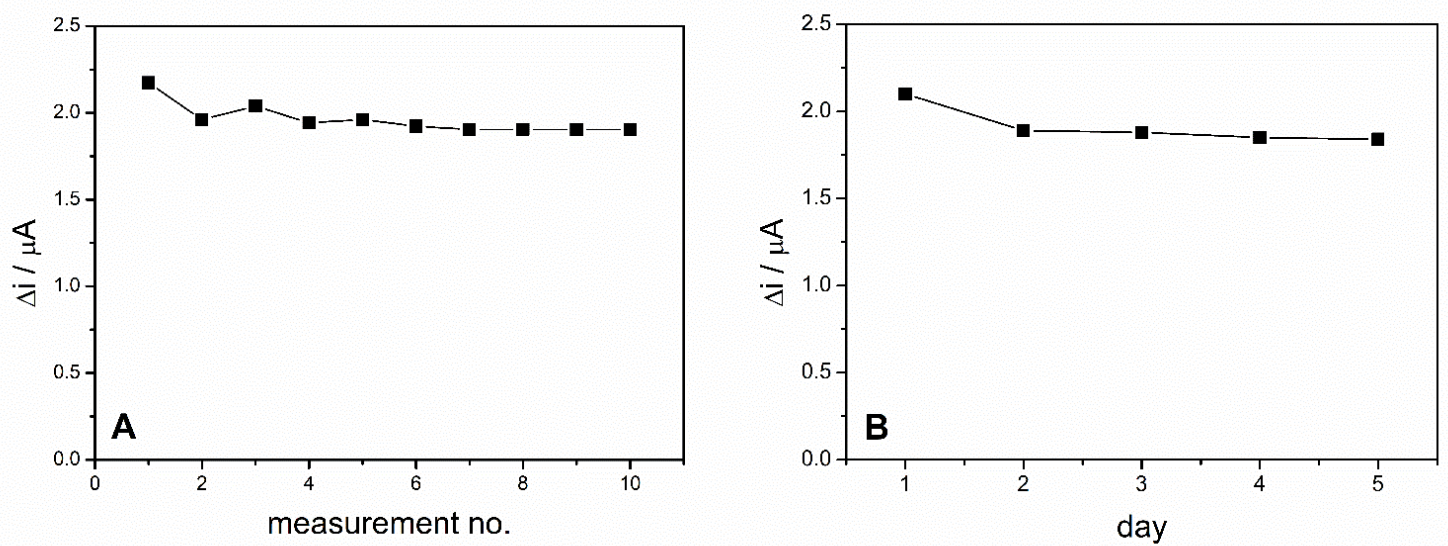

Figure 7. (A) Operational stability of the ADH-sol-gel/PAH/SPE biosensor. (B) Long term stability of the ADH-solgel $/ \mathrm{PAH} / \mathrm{SPE}$ biosensor $\mathrm{E}=+500 \mathrm{mV}$, PBS $0.1 \mathrm{M} \mathrm{pH}=8.8,\left[\mathrm{NAD}^{+}\right]=10 \mathrm{mM}$, ethanol $4 \mathrm{mM}$ ).

The long-term stability of the biosensor was studied by chronoamperometric measurements performed on the same biosensor every day for 5 days. Before each measurement, the biosensor was kept for $15 \mathrm{~min}$ in PBS $\mathrm{pH}=8.8$ and when not in use, was stored in the desiccator at $4{ }^{\circ} \mathrm{C}$. The biosensor exhibited a decrease of the response with $10 \%$ in the second day and then maintained relatively constant for the next days (Figure 7B).

\subsection{Selectivity of the ADH-Sol-Gel/PAH/SPE Biosensor}

The selectivity of the biosensor was evaluated in the presence of compounds such as ascorbic acid (AA), uric acid (UA), acetaminophen (APAP), dopamine (DA) and glucose (Glu) present in various real samples that are reported as potential interferents in the 
detection of ethanol. Amperometric measurements were performed in the optimized conditions for detection of ethanol, previously reported by successive addition of ethanol and interfering compound in a molar ratio of 1:1.

Table 2 shows the current ratios calculated as the report between the steady-state current after addition of interfering compounds in a solution of $1 \mathrm{mM}$ ethanol and the current recorded in $1 \mathrm{mM}$ ethanol before the addition of the interferent. As can be seen, only acetaminophen interferes with the detection of ethanol, leading to an increase of the signal with $18 \%$. These results allowed us to conclude that the detection of ethanol with the developed biosensor can be performed without the occurrence of possible interferences for food product including alcoholic beverages.

Table 2. Influence of interfering compounds on the detection of ethanol.

\begin{tabular}{cc}
\hline Interfering Compound & $\begin{array}{c}\text { Current Ratio } \\
\text { E:I } \mathbf{~ = ~ 1 : 1 ~}\end{array}$ \\
\hline Glucose & 1.0 \\
Uric acid & 1.0 \\
Dopamine & 0.9 \\
Ascorbic acid & 0.95 \\
Acetaminophen & 1.18 \\
\hline
\end{tabular}

${ }^{1}$ Current ratio $=\mathrm{I}_{\mathrm{E}+\mathrm{I}} / \mathrm{I}_{\mathrm{E}}$ where $\mathrm{I}_{\mathrm{E}+\mathrm{I}}=$ response of $1 \mathrm{mM}$ ethanol $(\mathrm{E})$ in presence of interfering compounds (I) and $\mathrm{I}_{\mathrm{E}}=$ response of $1 \mathrm{mM}$ ethanol in the absence of interfering compounds.

\subsection{Detection of Ethanol in Alcoholic and Non-Alcoholic Beverages Samples}

The ADH-sol-gel/PAH/SPE biosensor was used to detect ethanol in commercial beer. One alcoholic and one non-alcoholic beer from the same trademark were used in this study and each sample was analyzed in triplicate. The ethanol content reported on the bottle label is $5 \%$ vol, which represents a molar concentration of $0.86 \mathrm{M}$. The beer sample was diluted 1:40 before measurements and $100 \mu \mathrm{L}$ of the diluted sample was added in the $5 \mathrm{~mL}$ electrochemical cell, containing $0.1 \mathrm{M} \mathrm{PBS} \mathrm{pH}=8.8$ and $10 \mathrm{mM} \mathrm{NAD}^{+}$.

Ethanol concentration was calculated using the second linear range of the biosensor for the alcoholic beer sample. The determined ethanol content was $0.93 \pm 0.06 \mathrm{M}$ yielding to a $108 \%$ recovery.

The currents recorded in the case of non-alcoholic beer sample were below the detection limit and addition of ethanol $1 \mathrm{mM}$ leads to a recovery of $1.06 \mathrm{mM}$.

The ethanol concentration found in the alcoholic beer showed a good agreement with the ethanol content declared by the producer.

\section{Conclusions}

This study reports the development of a new enzyme biosensor based on alcohol dehydrogenase for the detection of ethanol in beverages. The electrochemical oxidation of $\mathrm{NADH}$, performed at low potential with respect to a silver pseudo-reference electrode, is supported by coating the carbon screen printed electrode with a layer of poly(allylamine hydrochloride) that enhances the accumulation of the NADH at the surface of the modified electrode and leads to an increase of the oxidation current of this compound [18]. The enzyme was immobilized using a sol-gel matrix that preserves the enzyme activity and ensures fast diffusion of the coenzyme to the surface of the electrode. The main parameters, such as working potential and $\mathrm{pH}, \mathrm{NAD}^{+}$concentration, storage condition, were optimized. The ADH-sol-gel/PAH/SPE biosensor exhibits a large dynamic response range, fast response, high sensitivity, low detection limit with good stability and repeatability. Moreover, the biosensor proposed in this work present the advantage of being easy to fabricate, store and operate and would have great potential application in determination of ethanol in alcoholic beverages and food. 
Author Contributions: Conceptualization, L.R. and O.M.I.; methodology, L.R.; validation, L.R. and C.B.; writing-original draft preparation, O.M.I.; writing-review and editing, L.R. and C.B.; supervision, L.R. and C.B.; funding acquisition, C.B. All authors have read and agreed to the published version of the manuscript.

Funding: This work was supported by a grant from the Romanian Ministry of Research, Innovation and Digitization, CNCS/CCCDI-UEFISCDI, project no PN-III-P4-ID-PCE2020-0998, within PNCDI III.

Acknowledgments: Oana-Maria Istrate gratefully acknowledges the ICUB Fellowship no. 15260/2020. We thank Virgil Marinescu from ICPE-CA for SEM images recording.

Conflicts of Interest: The authors declare no conflict of interest.

\section{References}

1. Avila, L.M.; dos Santos, A.P.F.; de Mattos, D.I.M.; de Souza, C.G.; de Andrade, D.F.; d'Avila, L.A. Determination of ethanol in gasoline by high-performance liquid chromatography. Fuel 2018, 212, 236-239. [CrossRef]

2. Ye, Q.; Yu, Y.; Qu, R.; Fang, Z. Rapid and quantitative detection of ethanol proportion in ethanol-gasoline mixtures by Raman spectroscopy. Opt. Commun. 2009, 282, 3785-3788. [CrossRef]

3. Oliver, J.D.; Sutton, A.T.; Karu, N.; Phillips, M.; Markham, J.; Peiris, P.; Hilder, E.F.; Castignolles, P. Simple and robust monitoring of ethanol fermentations by capillary electrophoresis. Biotechnol. Appl. Biochem. 2015, 62, 329-342. [CrossRef]

4. Shahvar, A.; Shamsaei, D.; Saraji, M. A portable smartphone-based colorimetric sensor for rapid determination of water content in ethanol. Measurement 2020, 150, 107068. [CrossRef]

5. Shih, C.-J.; Smith, E.A. Determination of glucose and ethanol after enzymatic hydrolysis and fermentation of biomass using Raman spectroscopy. Anal. Chim. Acta 2009, 653, 200-206. [CrossRef] [PubMed]

6. Bastidas-Oyanedel, J.-R.; Mohd-Zaki, Z.; Pratt, S.; Steyer, J.-P.; Batstone, D.J. Development of membrane inlet mass spectrometry for examination of fermentation processes. Talanta 2010, 83, 482-492. [CrossRef] [PubMed]

7. Tiscione, N.B.; Alford, I.; Yeatman, D.T.; Shan, X. Ethanol Analysis by Headspace Gas Chromatography with Simulta-neous Flame-Ionization and Mass Spectrometry Detection. J. Anal. Toxicol. 2011, 35, 501-511. [CrossRef] [PubMed]

8. Wang, Y.; Xu, H.; Zhang, J.; Li, G. Electrochemical Sensors for Clinic Analysis. Sensors 2008, 8, 2043-2081. [CrossRef] [PubMed]

9. Istrate, O.-M.; Rotariu, L.; Bala, C. Amperometric L-Lactate Biosensor Based upon a Gold Nanoparticles/Reduced Gra-phene Oxide/Polyallylamine Hydrochloride Modified Screen-Printed Graphite Electrode. Chemosensors 2021, 9, 74. [CrossRef]

10. Angeloni, R.; Tomassetti, M.; Castrucci, M.; Campanella, L. Ethanol Determination in Alcoholic Beverages Using Two Different Amperometric Enzyme Sensors. Curr. Anal. Chem. 2014, 11, 56-67. [CrossRef]

11. Bilgi, M.; Ayranci, E. Biosensor application of screen-printed carbon electrodes modified with nanomaterials and a con-ducting polymer: Ethanol biosensors based on alcohol dehydrogenase. Sens. Actuator B Chem. 2016, 237, 849-855. [CrossRef]

12. Soylemez, S.; Kanik, F.E.; Uzun, S.D.; Hacioglu, S.O.; Toppare, L. Development of an efficient immobilization matrix based on a conducting polymer and functionalized multiwall carbon nanotubes: Synthesis and its application to ethanol biosensors. J. Mater. Chem. B 2014, 2, 511-521. [CrossRef]

13. Adhikari, B.-R.; Schraft, H.; Chen, A. A high-performance enzyme entrapment platform facilitated by a cationic polymer for the efficient electrochemical sensing of ethanol. Analyst 2017, 142, 2595-2602. [CrossRef]

14. Barhoumi, L.; Istrate, O.-M.; Rotariu, L.; Ben Ali, M.; Bala, C. Amperometric Determination of Ethanol using a Novel Nanobiocomposite. Anal. Lett. 2017, 51, 323-335. [CrossRef]

15. Li, L.; Lu, H.; Deng, L. A sensitive NADH and ethanol biosensor based on graphene-Au nanorods nanocomposites. Talanta 2013, 113, 1-6. [CrossRef] [PubMed]

16. Han, Z.; Wang, Y.; Duan, X. Biofunctional polyelectrolytes assembling on biosensors-A versatile surface coating method for protein detections. Anal. Chim. Acta 2017, 964, 170-177. [CrossRef] [PubMed]

17. Barsan, M.M.; Ghica, M.E.; Brett, C.M.A. Electrochemical sensors and biosensors based on redox polymer/carbon nanotube modified electrodes: A review. Anal. Chim. Acta 2015, 881, 1-23. [CrossRef] [PubMed]

18. Rotariu, L.; Istrate, O.-M.; Bala, C. Poly(allylamine hydrochloride) modified screen-printed carbon electrode for sensitive and selective detection of NADH. Sens. Actuators B Chem. 2014, 191, 491-497. [CrossRef]

19. Dave, B.C.; Dunn, B.; Valentine, J.S.; Zink, J.I. Sol-gel encapsulation methods for biosensors. Anal. Chem. 1994, 66, 1120A-1127A. [CrossRef]

20. Walker, J. Spectrophotometric determination of enzyme activity: Alcohol dehydrogenase (ADH). Biochem. Educ. 1992, 20, 42-43. [CrossRef]

21. Azzouzi, S.; Rotariu, L.; Benito, A.; Maser, W.K.; Ben Ali, M.; Bala, C. A novel amperometric biosensor based on gold nanoparticles anchored on reduced graphene oxide for sensitive detection of l-lactate tumor biomarker. Biosens. Bioelectron. 2015, 69, 280-286. [CrossRef]

22. Hou, C.T.; Patel, R.; Barnabe, N.; Marczak, I. Stereospecificity and other properties of a novel secondary-alcohol-specific alcohol dehydrogenase. JBIC J. Biol. Inorg. Chem. 1981, 119, 359-364. 
23. Casero, E.; Petit-Domínguez, M.D.; Vázquez, L. Enzymatic Sol-Gel Biosensors. In Handbook of Sol-Gel Science and Technology; Klein, L., Aparicio, M., Jitianu, A., Eds.; Springer International Publishing: Cham, Switzerland, 2016; pp. 1-39.

24. Bilgi, M.; Sahin, E.M.; Ayranci, E. Sensor and biosensor application of a new redox mediator: Rosmarinic acid modified screen-printed carbon electrode for electrochemical determination of NADH and ethanol. J. Electroanal. Chem. 2018, 813, 67-74. [CrossRef]

25. Gallay, P.; Eguílaz, M.; Rivas, G. Multi-walled Carbon Nanotubes Non-covalently Functionalized with Polyarginine: A New Alternative for the Construction of Reagentless NAD ${ }^{+}$/Dehydrogenase-based Ethanol Biosensor. Electroanalysis 2019, 31, 805-812. [CrossRef]

26. Malvano, F.; Albanese, D.; Sannini, A.; Crescitelli, A.; Pilloton, R.; Di Matteo, M. Ethanol Content in Must Grape by Alcohol Dehydrogenase Biosensors Based on Doped-Polyaniline Modified Screen Printed Electrodes. In Icheap12: 12th International Conference on Chemical \& Process Engineering; Pierucci, S., Klemes, J.J., Eds.; Aidic Servizi Srl: Milano, Italy, 2015; Volume 43, pp. 37-42.

27. Mao, X.Y.; Wen, Y.; Xiong, M.L.; Niu, Z.; Jiang, L.; Zhang, H.L.; Yang, L.J.; Chen, R.J. Electrochemical Biosensors Based on Carbon Nanocages for the Detection of NADH and Ethanol. Int. J. Electrochem. Sci. 2021, 16, 11.

28. Kochana, J.; Adamski, J. Detection of NADH and ethanol at a graphite electrode modified with titania sol-gel/Meldola's Blue/MWCNT/Nafion nanocomposite film. Open Chem. 2012, 10, 224-231. [CrossRef]

29. Samphao, A.; Kunpatee, K.; Prayoonpokarach, S.; Wittayakun, J.; Švorc, L'.; Stankovic, D.M.; Zagar, K.; Ceh, M.; Kalcher, K. An Ethanol Biosensor Based on Simple Immobilization of Alcohol Dehydrogenase on $\mathrm{Fe}_{3} \mathrm{O}_{4} @ \mathrm{Au}$ Nanoparticles. Electroanalysis 2015, 27, 2829-2837. [CrossRef]

30. Hua, E.; Wang, L.; Jing, X.; Chen, C.; Xie, G. One-step fabrication of integrated disposable biosensor based on ADH/NAD+/meldola's blue/graphitized mesoporous carbons/chitosan nanobiocomposite for ethanol detection. Talanta 2013, 111, 163-169. [CrossRef] [PubMed]

31. Niculescu, M.; Erichsen, T.; Sukharev, V.; Kerenyi, Z.; Csöregi, E.; Schuhmann, W. Quinohemoprotein alcohol dehydro-genasebased reagentless amperometric biosensor for ethanol monitoring during wine fermentation. Anal. Chim. Acta 2002, 463, 39-51. [CrossRef] 